DOI: $10.31866 / 2410-1915.21 .2020 .208241$

UDC 394.2:321.64(47+57)

\title{
SOVIET HOLIDAYS AND CEREMONIES AS AN UNSUSTAINABLE SOCIOCULTURAL EXPERIMENT
}

\section{Oleksander Kurochkin}

Doctor of History, Professor, ORCID:0000-0002-3365-7266,olexkuro@gmail.com, Kyiv National University of Culture and Arts, 36, Ye. Konovaltsia St., Kyiv, 01133, Ukraine

\section{For citations:}

Kurochkin, O. (2020). Soviet Holidays and Ceremonies as an Unsustainable Sociocultural Experiment. Culture and Arts in the Modern World, 21, 116-130. https://doi.org/10.31866/24101915.21.2020.208241.

The purpose of the article is to analyse the practice of forming a system of Soviet holidays and ceremonies with a critical mind, to reveal their inhumane, totalitarian nature and tasks and objectives mismatching to a democratic society building. The article uses general scientific methods of analysis and synthesis. The historical approach helped to accumulate primary data obtained from primary sources and literature on the selected topic. The axiological method made it possible to consider the value content and social value of Soviet ritualism. The scientific novelty of the article is determined by the fact that for the first time in domestic culturology the processes of introduction and transformation of Soviet holidays and ceremonies in Ukraine are covered in the context of the formation of the ideology of the totalitarian regime. The concrete facts show that from the very beginning the Bolshevik government pursued a policy of forced secularisation of the population, ousting from life (primarily public) all forms and manifestations of religious and traditional folk rituals. Conclusions. In its development, Soviet holidays and ceremonies went through several stages, each of which corresponded to a certain period of formation of socioeconomic relations in the Soviet Union, an urgent task in the field of transformation of ideology and culture. The core of the system of holiday dates of the "red calendar" were the anniversaries of the Great October Socialist Revolution, the Day of International Solidarity of Workers, the Day of the Paris Commune. The official models and scenarios of these celebrations took canonical forms during the years of complete domination of Stalin's totalitarian dictatorship. The so-called new socialist customs and rites suffered from excessive regulation, false pathos, the overdose of communist propaganda, and therefore, not in vain, they were compared with artificial flowers. One of the main shortcomings of the Soviet all-Union ritual, which eventually led to its complete bankruptcy, should be considered complete disregard for the identity of the culture of individual peoples who inhabited the USSR.

Keywords: Soviet holidays and ceremonies; communist totalitarianism; atheistic propaganda; holiday calendar; national identity; democratic society.

(C) Oleksander Kurochkin, 2020 


\section{Introduction}

Throughout the post-Soviet and post-Socialist states, the cardinal transformations of the last decades have been carried out under the slogans of liberation from the totalitarian past, deideologization of all spheres of spiritual and social life. This tendency manifests itself in the refusal of old ideological myths and doctrines, in the shift away from the canons of rigid programming and political formality. The loss of interest in holidays, customs and traditions of the socialist era, associated with the underlying values, is observed everywhere. Along with the destruction of "Soviet civilisation", there is an accelerated process of decomposition of the nationalised and centralised "socialist festive and ceremony system". Consequently, the one-dimensionality of a single exemplary standard disappears together with the sense of belonging to a specific "international community" (in fact, artificially invented one).

Each ethnic and social community (tribe, people, state, nation) forms its own calendars comprising the dates of holidays, customs and traditions. Such calendars reflect previous historical experience of the community and outline the prospects for the future. This is fully applicable to modern Ukrainian society, which is on the path of transition from "planned socialism" to a market economy, from Bolshevik totalitarianism to liberal democracy.

The current reconstruction of the festive and ceremony system in Ukraine should be regarded as an evolutionary form of transition, which involves the gradual replacement of ritual traditions, their modernisation and consolidation in the family, social and domestic spheres. According to the philosophers' observations, the transformation process includes “... and destruction, and alteration of the old, and its adequate reproduction, and hybridisation of the old and new, that is, mixed forms. Transformational movement is multivariate" (Krymskyi, 2003, p. 208).

Throughout the entire Bolshevik Regime, the issue of Soviet holidays and ceremonies was covered in scientific literature and journalism in an apologetic manner. The newly created elements of socialist culture were glorified and propagandised in every possible way as "an important means of Communist education of workers", "a reliable mechanism for establishing the Soviet way of life", "an effective method of combating religious and nationalistic holdover", etc. Western political scientists initiated the critical direction of historiography towards assessing the so-called Communist traditions and rituals. It became relevant in the countries of the former "Communist bloc" only after its collapse and the wreck of the entire system of ideological censorship.

An important theoretical and methodological reference point became the pioneer work "Totalitarian State" by Zhelyu Zhelev, a Bulgarian philosopher. Depending on objective documentary materials, the scientist proved that "there is no significant difference between the Nazi and Communist political systems, but if there is any - it is not in favour of communism" (Zhelev, 1991, p. 7).

At the turn of the $20^{\text {th }}$ and $21^{\text {st }}$ centuries, some new studies appeared that debunked the dogmas and mythologems of "Soviet civilisation". It is worth giv- 
ing prominence to those that have helped us to highlight our issues in a methodological and meaningful way.

R. Ivanova, a Bulgarian ethnologist, who studied the transformation processes of the festive sphere, found a lot in common with folklore and traditional ritual culture in them. She suggests treating holidays, rallies and demonstrations of the liberation from totalitarian regimes period as a kind of transitional rites (rites de passage) on the verge of two epochs. Besides, she distinguishes an ancient folklore model of festive behaviour in political slogans, implying that "the top" is thrown down, and "the bottom" is raised. Thus, the central mythological triad of "life-death-new life" is resurrected in the modern political discourse (Ivanova, 1997, p. 320).

The "Rites and holidays" research by A. Riznyk and A. Hrytsenko was published in 1998, when the process of decommunisation was just gaining momentum in our country. This did not prevent the authors, rejecting Soviet ideological clichés, from developing an innovative concept of the festive and ceremony culture evolution on the territory of Ukraine from the pagan era to the present day. They regard a holiday and celebration as phenomena of popular culture, which are clearly based on "splitting into a sacral and secular, actually leisure, part” (Riznyk \& Hrytsenko, 1998, p. 482).

The archetypical construction of a holiday is interestingly interpreted by ethnologists A. Abramian and A. Shagoian. In their opinion, Soviet holidays are subject to the general rule of transition from the structure to anti-structure, from the Universe to Chaos. Moreover, they assume that pompous parades, along with demonstrations, are "a kind of super-compressed model of Soviet society” (Abramian \& Shagoian, 2002, p. 37).

The publication by Yu. Kahanov (2013), containing an extensive documentary material, reveals the ideological aspect of Soviet holidays' introduction in Ukraine and the manifestations of oppositional public mood towards this political campaign.

The author of these lines has also contributed to the disclosure of the specified issues (Kurochkin, 2014; 2018). The subject of our analysis was trends in the development of the festive and ceremony culture of the last century in Ukraine. As the research materials have demonstrated, such a mass form of human activity is sensitive to changes in the socio-economic, political and cultural environment, thus confirming the fact that no one and nothing can avoid the pressure of history. It is worth providing the idea of K. Zhigulskii, a Polish sociologist, now, that is: "The festive rites can be explained only in the light of historical knowledge” (Zhigulskii,1985, p. 141)

\section{Purpose of the article}

The purpose of the article is to analyse the practice of developing the system of Soviet holidays and ceremonies with a critical mind and to reveal their anti-human, totalitarian nature as well as its inconsistency with the tasks and objectives of building a democratic society. General scientific methods such as analysis and synthesis have been applied in the article. The historical approach 
contributed to the accumulation of primary data obtained from original sources and literature on the chosen topic. The axiological approach allowed us to consider the valuable content and social value of Soviet ritualism.

\section{Main research material}

Having come to power under the flag of democratic individual rights and freedoms together with all workers' equality, the Bolsheviks, in reality, built a barrack-type society in the USSR, where the institutions of democracy were unrecognisably distorted. However, they continued to be declared.

In their development, Soviet holidays and rites have passed through several stages. Each of them corresponded to a certain period of socio-economic relationship formation in the country of the Soviet Union and urgent tasks in the field of the ideology and culture transformation. From the very beginning, the Bolshevik regime implemented a policy of forced secularisation of the population, within the framework of which all forms and manifestations of religious ritualism were consistently banned and ousted from everyday life (the primarily public one). Clergymen of both Christian and non-Christian faiths and denominations became the victims of cruel and mass repressions. The Soviet authorities persecuted the clergy and believers, destroyed churches, and plundered cult values. The Soviet rule separated Church from the state, school from Church and established freedom of faith and atheism. Besides, it abolished all the privileges for the clergy and introduced legal regulation of marriage and family relations to devalue the influence of the Church on the population.

The foundations of the Soviet festive and ceremony system were laid in the 1920s, the period of the so-called "Red Ceremonialism". At that time, "red weddings", "red baptisms", public dirges and "red funerals" started to be held to resist the Church ceremonialism. The most active members of the Komsomol and the Party organised "red Easter" and "red Christmas", accompanied by mass-agitation performances and entertainments.

The widespread celebration of "Komsomol Christmas" or "red Kolyada" took place in Ukraine in 1922-1923. The "hurrah-for-atheism" attitude is vividly expressed in the revolutionary slogans of this epoch:

The old bends

And rubs against ash.

The gods escape the altars.

(The "Selianska Pravda" newspaper, 1922).

The newly proclaimed Soviet regime applied such common forms of mass political agitation as meetings, demonstrations, processions with red flags, theatrical performances dedicated to revolutionary events and memorable dates. In these planned events, A. Lunacharskii notices a spontaneous manifestation of folk art and an unprecedented enthusiastic drive of people of the new society. He pathetically declared in 1920: "It is absolutely indisputable that popular fests have always been and will remain the main artistic product of the revolution" (Lunacharskii, 1981, p. 84). Unfortunately, the next step in the history of Soviet society failed to confirm this optimistic prophecy. 
According to the plan of the Bolshevik ideologists, the "new Soviet ceremonialism" was supposed to fundamentally differ from the old one - a religious and deeply alien mindset of the socialism builders. However, they did actively use the models and canons of Church festivities, transforming them in their own way: liturgies gave way to party meetings, short hymns and acaphistus - to revolutionary songs, icons and crosses - to portraits of the leaders of the revolution, and so on.

The red five-pointed star became an indispensable attribute of Soviet holidays. It symbolised brotherhood and solidarity of workers from all continents of the Earth. At first, there were a plough and a hammer depicted on the star the tools of a peasant and a worker. In 1922, the plough and hammer were replaced with the hammer and sickle (Gavriliuk et al., 1988, p. 93).

In the first years after the Bolshevik Revolution, a new tradition was set up, namely to celebrate "Communist subbotniks" as a form of voluntary work for the general welfare. According to the ceremony, a short meeting was held before the start of the subbotnik. The meeting was followed by delivering an order, due to which the participants dispersed to their workplaces to the strains of an orchestra, singing revolutionary songs and carrying banners. In rural culture, new forms of labour ceremonials arose. They were associated with the rejection of the old equipment ("burial of the sokha"), as well as the approval of a new one (greeting of the first tractor and other agricultural machines). It is important to note that the "Red Ceremonialism" of the 1920s had a political campaign nature. It was marked by elements of formalism, declarativity, militant atheism, and therefore it failed to find a widespread support among the masses.

To establish in Russia the same reckoning as other countries had, the Gregorian calendar was brought into force replacing the Julian calendar, which lagged by 13 days, by the decree of the Council of People's Commissars on January 24 (February 6). It was also the time when the process of creating a new system of memorable holiday dates began, inheriting the experience of the Great French Revolution of 1789-1793. The core of the "red calendar" was the anniversary of the Great October Socialist Revolution, International Workers' Solidarity Day - the 1st of May, the Day of the Paris Commune. Official models and scenarios of these celebrations acquired canonical forms at the second stage of the system of Soviet holidays and ceremonies formation during the years of complete dominance of Stalin's totalitarian dictatorship. In the Bolshevik mythology, the October of 1917 was perceived as a holiday of "primordium", a memorable milestone, from which the entire subsequent history of "progressive humanity" was counted. In Soviet times, this holiday was qualified as the most important "holiday of holidays", as "an international holiday of all Soviet peoples and at the same time a national holiday of each nation" (Kampars \& Zakovich, 1967, p. 45). The main idea of the October celebrations was realised in the public sphere with the help of such proven means of festive integration as parades, demonstrations, solemn assemblies, meetings, concerts, athletic shows, etc. All these events were carefully prepared and organised. The scenarios of festive celebrations, approved in the party bodies, clearly defined the necessary slogans, attributes, the number of participants, responsible persons and completely excluded any improvisation and amateur activity. 
Cultural specialists V. Riznyk and A. Hrytsenko (1998) note: "The centralisation of the "festive business" in the USSR led to the development of a standard and consistently observed scheme of holding festivities, which in each case differed only in the degree of completeness (depending on the level of the political significance of the holiday)" (p. 491).

May Day also belonged to the rank of central and fundamental holidays. It was established in honour of the heroic demonstration of Chicago workers on May 1,1886, when thousands of people took to the streets of the city to demand an 8-hour working day and better working conditions. The demonstration was shot, which caused a wave of outrage in many countries around the world. In July 1889, the Founding Congress of the Second International decided to celebrate the annual day of workers' unity and brotherhood. Since then, May Day has gained worldwide recognition as a holiday of international solidarity and struggle for the rights of all wage earners.

The culmination of the most celebrated public holidays in the USSR (November 7 , May 1 ) was pompous military parades aimed at demonstrating the power and greatness of the Soviet system and its support, namely "the army of workers and peasants". The role model was the ceremony on Red Square in Moscow, which were broadcasted by radio and television throughout the country and abroad. Somewhat more modestly, but on the same scenario, military parades were held in the capitals of the Union Republics, major cities and regional centres.

The traditional Soviet ritual of celebrating the October revolution anniversary and May Day necessarily included a solemn demonstration. A large number of people, carrying portraits, flags and banners, took part in a march along the main street or square of the city past the podium with the leadership of a certain level: republican, regional, district and city. There were representatives of industrial, educational, medical and other staffs. The mausoleum where the body of V. I. Lenin was kept, was considered to be the all-Union tribune from which the Central Committee of the CPSU and the government greeted the festive procession of workers. The propaganda purpose of the ceremonial march consisted in magnifying the advantages of the socialist system, affirming "the inviolable union" of the people with the "native Communist party - the organiser and inspirer of all victories". Participation in demonstrations was considered to be an honourable duty, and it was strictly controlled by the relevant party bodies, heads of administration and trade unions. The order of marching, the number of essentials, the theme of slogans and background music were defined in the pre-approved plan of festive events. Any deviation from the approved scenario was considered as errors in the ideological work.

Directive imposing of the new system of holidays and ceremonies was not conflict-free. Yu. Kahanov (2013) assumes this process "was met with resistance by a part of the non-conformist Ukrainian population, which felt the hidden intention of emasculating and leveling their national traditions and religiosity..." (p. 191). He supports his conclusion providing a number of eloquent documents which illustrate the critical attitude of people to the Soviet ritualism. As a rule, such cases were carefully concealed, and the information about 
them was stored in the archives of the special services marked as "top secret" (Kahanov, 2013, p. 191).

Even in the most difficult totalitarian years, the festive time remained a kind of "island of freedom". It allowed a person, either secluded or in the circle of relatives and friends, to get rid of sad facts of life at least for a while. A festive atmosphere opened up opportunities to meet basic life and cultural needs, promoted emotional release and relaxation. Having got rid of ideological censorship, people freely exchanged news and political jokes, sang, listened to music, had fun, etc. at the festive table. The celebratory "relief" was felt even by prisoners of Stalin's correctional camps and prisons. During the great revolutionary holidays, the punitive regime was somewhat relaxed, and one could hope for a surplus to the poor food rations.

In the Communist ideology system, Soviet Army and Navy Day, celebrated on February 23, was assigned the role of a sufficient incentive for militarypatriotic propaganda and strengthening the "inviolable unity" of the people and their army. Since most men were involved in military service in one way or another, the holiday celebrated on February 23 was gradually transformed into a universal “Men's Day” in the USSR, akin to International Women's Day on March 8.

Prominent rites in the system of the all-Union ceremonialism were anniversaries of the USSR and "fraternal republics" establishment, anniversaries of the Communist party, significant dates from the history of the CPSU, the All-Union Leninist Young Communist League and the international proletarian movement. It is noteworthy that all of them were celebrated only at the official level and did not concern the sphere of family and household life.

Domestic cultural scientists conclude that the Soviet "aggressive policy" of penetrating festivity into the culture, carried out in the USSR, "to a large extent shattered the ideas about holidays, and even caused their devaluation" (Riznyk \& Hrytsenko, 1998, p. 493). Significantly, the regular party congresses and plenums of the CPSU, elections to the Soviet of People's Deputies, etc. were ranked as "national holidays". Brass bands performances and trading "scarce goods" became prominent characteristic decorations of such "festive" events.

An essential role in the formation of the socialist way of life and the Communist education of workers belonged to the cult of the leaders of the CPSU and especially the figure of V. I. Lenin, "the creator of the Bolshevik party and the USSR". Reasonably considering the Soviet ideology as a specific quasi-religion, the image of Lenin appeared to be an idol or an icon. No public holiday or ritual was complete without a portrait or sculpture of the "leader of all proletarians". There were so-called "Leninist exams" at high schools, "Leninist lessons" at schools, "Leninist shifts" at factories. Special Lenin museums, rooms and corners were associated with pioneer celebratory assemblies, admission to the pioneers, Komsomol members, the solemn presentation of passports of the USSR citizens, and so on. Anniversaries of Lenin's birthday had been celebrated since 1925 and were considered to be among the most important dates of the "red calendar". The central pathos of this holiday consisted in the adoption of Lenin's theoretical heritage by the masses and the propaganda of the Soviet system achievements. 
Excessive fetishising of Lenin's image gained a truly cosmic momentum and forms, clearly going beyond the bounds of sound mind. Let us provide just one vivid example of a laudatory-jubilee empty talk, signed by a certain Viktor Romanyuk:

Every stalk glows with Lenin,

Every person glows with Lenin,

The entire world glows with Lenin.

The Universe, sunlit by greatness of Lenin,

The Universe, fanned with eternity of Lenin,

Set off for happiness in flight.

During the brutal Stalinist terror and famine, when millions of people worked hard in correctional camps, on zones, and at collective farms (the kolkhozes) for bread rations, new professional holidays and labour celebrations were pompously introduced in the USSR. It was the period when Railroad Workers Day, Miner's Day, and others were legislated.

The rites of initiation into workers, farmers, honouring the winners of the socialist competition were introduced into practice in labour collectives. The main goal of these events was to activate the human factor in the sphere of labour employing ideological manipulation to successfully implement the Party's plans for "Stalin's five-year plans".

Western Sovietologists jested that in the USSR "every dog has its own holiday", observing how more and more new professional holidays appeared in the country: Engineer's Day, Stock-Breeder's Day, Utility Worker's Day, etc. Taking into account the constant trend of modern high-tech production to allocate new professional specialisations, the number of which significantly surpasses 1000 , the attempts to provide all employees with their professional holidays tend to create absurd projects.

The totalitarian Bolshevik regime was built on the principles of monarchy and bureaucratic centrism. Therefore it was always hostile to various forms and manifestations of local, regional, and even more of national identity. In this regard, participants of mass events in Kyiv on May 22, devoted to the reburial of Taras Shevchenko on the Chernecha hill in Kaniv, were harshly repressed by the authorities. The prohibition against celebrating the events and dates that cultivated historical memory and national identity was a characteristic feature of the Soviet ideological discourse.

The $60-80$ s of the $20^{\text {th }}$ century cover the third stage of the Soviet holidays and ceremonials system formation. In the atmosphere of relative democratisation of Soviet society after the condemnation of Stalin's cult, a mass rite-creating movement began in the USSR. It was during this period that calendar folk traditions, adapted to current conditions and the least influenced by Church dogmas, became widespread in many regions of Ukraine. It refers to the customs and folklore of New Year, parting with the Winter (Masnytsia, Spring Welcoming, Kupala Night, Harvest Festival (Obzhynky) and some others. In the capacity of secondary regenerated forms of folklore, they entered the Soviet ceremonials system, having undergone the corresponding ideological adjustment with the obligatory apologetics of the existing state structure. 
At the same time, under the banner of militant atheism, the rigid ideological doctrine, inherited from the Bolshevism, instilled a wary negative attitude towards the entire complex of ancient peasant rituals and folklore, which were identified as reactionary remnants. This course was introduced into practice not so much through agitation and persuasion but by methods of command and administrative pressure. Participants of traditional New Year's rounds with "Malanka", "Goat”, Christmas "Star" and Nativity Play were often fined, jailed for 15 days for violating public order. Secondary school students received lowered behaviour marks for participating in carolling, and so on. All this, of course, accelerated the natural extinction of authentic ceremonial customs.

In the general course of Communist propaganda, a significant culmination became Victory Day on May 9, established in 1965 by the Supreme Soviet of the USSR in commemoration of the victory over Nazi Germany in World War II. Monuments, obelisks, crosses, mass graves, the Tombs of the Unknown Soldier, the Mounds of Glory play an essential role in the figurative symbolism of this holiday. They are dedicated to all those who gave their lives for the freedom and independence of the Fatherland. A convenient for the ruling regime perception of the War, including its causes and consequences, was imposed on the Soviet people's consciousness using carefully selected slogans, examples, artworks and images, symbolic promotional actions and rituals. The Soviet myth about the Great Patriotic War is still actively used in propaganda and ideological manipulations of totalitarian Putin's power over Russia.

Among the holidays that were born during the "developed socialism" period and which paved the way for the construction of a new democratic society, we should mention the Humoryna in Odessa. It was founded in 1973. But carnival laughter is difficult to restrain within specified limits. Scared by the growing scale of street "uncontrolled actions", and fearing possible ideological sabotage, the authorities banned the Humoryna in 1977. It was reborn decades later in 1987 during the wave of liberalisation of the Soviet regime under Mikhail Gorbachev (Kurochkin, 2018).

By the efforts of the local state party nomenclature, Ukraine assumed the position of the Union flagman in the field of Soviet ceremonials during "the Brezhnev stagnation”. It regularly hosted conferences, seminars and meetings dedicated to strengthening the role of new holidays, traditions, and rituals in the Communist education of workers. Books, pamphlets and booklets, covering various aspects of the current topic from a Marxist-Leninist perspective, were published in large circulations.

The dynamic activity was developed in 1969. The Commission on Soviet traditions, holidays and rites under the Council of Ministers of the Ukrainian SSR coordinated the efforts of the relevant departments under the Executive committees of regional, city, district, village and town Councils of the People's Deputies. Based on the generalisation of "best practices", for active implementation, the Republican Commission locally developed standard scenarios and recommendations for the celebration of Victory Day, the solemn presentation of passports of the USSR citizens, sending off to the Armed Forces of the USSR, initiation into workers and farmers, honouring veterans of labour, Knowledge Day, the solemn 
registration of marriage, a newborn, and so on. These methodological materials clearly normalised the usage of symbols and attributes, dictated the desired content of the participants' speeches in the ritual, leaving little room for improvisation and amateur performance. Therefore, depending on the stage size, the following parameters were offered for making the decoration of the place on the occasion of Victory Day: “...the Order of Victory: the diameter is up to $3 \mathrm{~m}$; the length of the ribbon depicting the Order of Glory - no more than $6 \mathrm{~m}$; the length of the oak and laurel branches - no less than $2 \mathrm{~m}$ each; the height of the figures no less than $80 \mathrm{~cm}$ " ("Rekomendatsii po vidznachenniu", 1981, p. 21).

A characteristic feature of the artistic and aesthetic design of civil ceremonials in Ukraine was the widespread use of folk music and emotion-laden elements of folk festive traditions.

A unified system of training and retraining of personnel capable of professionally conducting ceremonial work was created in the USSR. Considerable attention was paid to the development and functioning of the ceremonial and ritual services. The material and technical base of these processes were provided by an extensive network of special institutions such as the Palace of Happiness, the Room of Happiness, holiday halls, salons, ritual services companies, ritual supplies stores, etc.

The so-called new socialist customs and ceremonials suffered from excessive regulation, false pathos, and an overdose of Communist propaganda. Thus, it is not for nothing that they were compared to artificial flowers. Among the main drawbacks of purposeful activity on the formation of all-Union ceremonials, which eventually led to the complete bankruptcy of the latter, one should name a total disregard of the identity of the individual peoples' culture, inhabiting the USSR, and the attempts to develop actually the same unified rites and holidays for everyone.

Only in the last decades of the Soviet Union, when it became fashionable to talk about perestroika and "socialism with a human face", the country's ideological control somewhat weakened, and, thus, helped to awaken democratic processes and initiatives. It was during the "Gorbachev's perestroika" that a new type of holiday, that is City Days, gained popularity in Ukraine and other Union republics. They were immediately positively perceived by the population and have now become traditional. But the initiative to introduce "alcohol-free holidays”, which was actively promoted in the framework of Gorbachev's antialcohol campaign of 1985-1986, proved to be a failure. It is best remembered for numerous jokes and ironic slogans such as "From an alcohol-free wedding to an immaculate conception".

The historical experiment, carried out in the USSR on the development and implementation of Soviet holidays and ceremonies in public and family life, was not viable in its final version. The rejection of the majority of Ukrainian society from the models and stereotypes of the Soviet-era ritualism in the context of building an independent state can be considered as one of the ways to overcome the recent totalitarian past.

Here are just a few eloquent facts that characterise the process of overcoming the legacy of Soviet traditions in independent Ukraine. The abolition of the 
colonial status in addition to the acquisition of state independence created the prerequisites for curtailing and eliminating the main all-Union holidays and the former metropolis's ones. The anniversaries of the Formation of the USSR and the "fraternal republics", the anniversaries of the Communist Party and its leaders, and significant dates from the history of the Komsomol and the international proletarian movement have passed away logically and painlessly.

The fall of the totalitarian regime was accompanied by a rapid devaluation of the Communist ideology and all associated values and authorities. This is clearly confirmed by a continual demolition process of monuments to V. I. Lenin on the territory of Ukraine, by which, according to the established canon, the chief official celebrations, all sorts of ceremonies and rituals tool place. It should be noted that in some regions (for example, in the West), "Leninopad" (Leninfall) was unfolding faster than in others (the East, the South). The degree of preservation of monuments and place-names of the Soviet regime on a specific territory seems to be able to serve as one of the indicators of political attitudes and sympathies of the local population.

In the context of the general impoverishment of the masses and the growing stratification of society, the populist ideals and symbols of the Soviet system have not lost their appeal to a large part of our citizens, especially the elderly. Therefore, it is not surprising that only in February 2000, the right-wing majority of the Ukrainian Parliament managed to legally cancel the celebration of the anniversary of the October revolution as a national holiday.

In recent years, there has been a noticeable desire to move away from the old totalitarian clichés in favour of new democratic forms of presentation of Victory Day. In particular, this is manifested in the refusal from holding pompous military parades and replacement of the Imperial St. George ribbon, which Putin's Russia boasts of, with a red poppy - a pan-European symbol of the memory of those who died in World War II.

In the context of modern political and economic realities, the attitude to International Workers' Solidarity Day, or May Day, has significantly changed in the society. Having lost its revolutionary pathos, this holiday has turned into a kind of spring break nowadays, when everyone is engaged into vital to them activities: resting, travelling, cultivating land in the country.

The indifferent attitude of the public to the "ideological stuffing" of official public holidays is a characteristic feature of our days. It is getting more and more complicated to coordinate the sacred and recreational functions of mass festive events.

Soviet holidays and ceremonies, which during the 1970s penetrated all spores of the Ukrainian society life, did not vanish simultaneously with the overthrow of the "socialist system". Their impoverished retro models are sometimes still replicated today, mainly due to the conservatism of the household sphere and the passivity of the creative asset. After moving away from the harsh policy of Soviet mass holidays, which functioned under the pressure of ideological censorship within the framework of internationalisation and the Russification levelling, the processes of sanctification today occur mostly spontaneously, without proper control, coordination and programming. The hope 
that everything will be resolved by itself, thanks to the spontaneous initiative of the masses, is deceptive and naive. If we do not want to live by other people's standards and customs, we should actively promote and implement our own ones, entrusting this responsible business to specialists. Here it is appropriate to refer to Karl Jaspers' philosophy, according to which the masses "should be told what they want" (Jaspers, 1994, p. 142). Besides, it is worth recalling the competent recommendation of Anatoly Lunacharskii: "A real holiday should be organised like everything else in the world that tends to make a highly aesthetic impression" (Lunacharskii, 1981, p. 85).

The rejection of the strict methods of the Soviet leadership should not result in the weakening of attention to the festive and ceremonial sphere. Further efforts of the public and specialists should be directed to the improvement of the artistic and organisational level of new Ukrainian holidays on a national scale. At the same time, we should take into account the fact that mass holidays are a special kind of art, characterised by its own laws, expressive means and drama. There is a need to create a scientific and methodological centre which could lead and coordinate work in this crucial area of sociocultural construction in our country.

\section{Conclusions}

Our comprehensive analysis, dedicated to the experience of the formation of the Soviet holidays and ceremonials system as an integral component of the Communist totalitarian ideology, has revealed its non-viability and incompatibility with modern development vectors of democratic Ukraine.

Shifts in the ideological superstructure of society, when the latter sharply changes the vector of its development, can be carried out by both revolutionary and evolutionary scenarios. The analysis of the evolutionary processes that took and are still taking place in the festive and ceremonial sphere of the Ukrainian society life during the independence era makes it possible to identify the main vectors of its further transformation. Firstly, it is the revival of ancient religious and folk festivals and rituals. Secondly, it is a modification, and more often a deliberate rejection of festive customs and behavioural stereotypes adopted in Soviet times. Thirdly, it is the creation and approval of new, previously unknown in our country, festive traditions in culture.

The Renaissance period in the evolution of the Ukrainian nation after gaining state independence, undoubtedly, contributed to the revival of interest in the problems of mentality, historical memory, national identity and cultural self-affirmation. In this regard, the desire to enrich the modern festive space with the help of the "national product", namely the folklore heritage of Ukrainians and various ethnic minorities, is noticeable. Turning to the rich sources of folk art will make it possible to actively resist the mechanical assimilation of unified consumer standards of mass culture.

The generally recognised system of festive and ceremony traditions is the backbone of the culture and spirituality of every nation. The satisfactory condition of this system affects all the spheres of the universal state organism life. The task is to ensure an active role of festive and ceremony culture in the pro- 
cesses of strengthening Ukraine's independence, consolidating the political nation, and establishing a civil society with high humanistic values.

\section{References}

Abramian, A., \& Shagoian, G. (2002). Dinamika prazdnika: giperstruktura, antistruktura [Holiday dynamics: hyperstructure, anti-structure]. Etnologicheskoe obozrenie, 2, 37-47 [in Russian].

Gavriliuk, N. K., Kurochkin, A. V.， Konvai, V. D., \& Popov, B. V. (Comps.). (1988). Sovetskie traditcii, prazdniki i obriady. Slovar-spravochnik [Soviet traditions, holidays and ceremonies. Dictionary dictionary]. Politizdat Ukrainy [in Russian].

Ivanova, R. (1997). Sbogom, dinozavri, dobre doshli krokodili! Etnologiya na promyanata [Goodbye, dinosaurs, welcome crocodiles! Ethnology of change]. Akademichno izdatelstvo [in Bulgarian].

Jaspers, K. (1994). Smysl i naznachenie istorii [The meaning and purpose of history] (M. Levina, Trans.). Respublika [in Russian].

Kahanov, Yu. (2013). Radianski sviata ta obriady u konteksti ideolohichnoi polityky v Ukraini druhoi polovyny XX stolittia [Soviet holidays and ceremonies in the context of ideological policy in Ukraine in the second half of the twentieth century]. Scholarly Works of the Faculty of History, Zaporizhzhia National University, 36, 186194 [in Ukrainian].

Kampars, P. P., \& Zakovich, N. M. (1967). Sovetskaia grazhdanskaia obriadnost [Soviet civil ceremonies]. Mysl [in Russian].

Krymskyi, S. B. (2003). Zapyty filosofskykh smysliv [Requests of philosophical meanings]. Parapan [in Ukrainian].

Kurochkin, O.V. (2014). Sviatkovyi rik ukraintsiv (vid davnyny do suchasnosti) [Festive year of Ukrainians (from ancient times to the present)]. O. V. Pshonkivskyi Publishing House [in Ukrainian].

Kurochkin, O. V. (2018). Sviatkovo-obriadova kultura. Vybrani pratsi [Festive and ceremony culture. Selected works]. Lira-K [in Ukrainian].

Lunacharskii, A.V. (1981). O massovykh prazdnestvakh, estrade, tcirke [About mass festivals, pop, circus]. Iskusstvo [in Russian].

Rekomendatsii po vidznachenniu Sviata Peremohy radianskoho narodu u Velykii Vitchyznianii viini 1941-1945 rokiv [Recommendations for celebrating the Victory Day of the Soviet people in the Great Patriotic War of 1941-1945]. (1981) [in Ukrainian]. Riznyk, O., \& Hrytsenko, O. (1998). Obriady i sviata [Rites and holidays]. In O. Hrytsenko, M. Strikha, V.Solodovnyk, Ye. Kononenko, \& O. Riznyk, Narysy ukrainskoi populiarnoi kultury [Essays on Ukrainian popular culture] (pp. 481-501). UTsKD [in Ukrainian].

"Selianska pravda" ["Peasant Truth"]. (1922, January 12). [in Ukrainian].

Zhelev, Zh. (1991). Totalitarnoe gosudarstvo [Totalitarian state]. Novosti [in Russian]. Zhigulskii, K. (1985). Prazdnik i kultura [Holiday and culture]. Progress [in Russian]. 


\section{РАДЯНСЬКІ СВЯТА І ОБРЯДИ ЯК НЕЖИТТЄЗДАТНИЙ СОЦІОКУЛЬТУРНИЙ ЕКСПЕРИМЕНТ}

\section{Курочкін Олександр Володимирович}

Доктор історичних наук, професор, ORCID: 0000-0002-3365-7266,olexkuro@gmail.com, Київський національний університет культури і мистецтв, Київ, Україна

Мета статті - критично проаналізувати практику формування системи радянських свят і обрядів, розкрити їхню антигуманну, тоталітарну сутність і невідповідність цілям і завданням побудови демократичного суспільства. У статті використано загальнонаукові методи аналізу і синтезу. Історичний метод допоміг у накопиченні первинних даних, отриманих із першоджерел та літератури з обраної теми. Аксіологічний метод дав змогу розглянути ціннісний зміст і соціальну вартість радянської ритуалістики. Наукова новизна статті визначається тим, що вперше у вітчизняній культурології процеси впровадження і трансформації радянських свят і обрядів в Україні висвітлюються у контексті формування ідеології тоталітарного режиму. На конкретних фактах показано, що від самого початку більшовицька влада здійснювала політику примусової секуляризації населення, витіснення 3 побуту (насамперед громадського) всіх форм і проявів релігійної і традиційно-народної ритуалістики. Висновки. У своєму розвитку радянські свята і обряди пройшли кілька етапів, кожний з яких відповідав певному періоду становлення соціально-економічних відносин у Країні Рад, актуальним завданням у сфері перетворення ідеології та культури. Ядром системи святкових дат «червоного календаря» стали річниці Великої Жовтневої соціалістичної революції, День міжнародної солідарності трудящих, День Паризької комуни. Офіційні моделі та сценарії цих урочистостей набули канонічних форм у роки цілковитого панування сталінської тоталітарної диктатури. Так звані нові соціалістичні звичаї і обряди страждали від надмірної регламентації, фальшивої патетики, передозування комуністичною пропагандою, i тому, недаремно, їх порівнювали зі штучними квітами. Однією з головних вад радянської загальносоюзної обрядовості, яка зрештою призвела до її повного банкрутства, слід визнати цілковите ігнорування самобутності культури окремих народів, які населяли СРСР.

Ключові слова: радянські свята і обряди; комуністичний тоталітаризм; атеїстична пропаганда; святковий календар; національна ідентичність; демократичне суспільство. 


\title{
СОВЕТСКИЕ ПРАЗДНИКИ И ОБРЯДЫ КАК НЕЖИЗНЕСПОСОБНЫЙ СОЦИОКУЛЬТУРНЫЙ ЭКСПЕРИМЕНТ
}

\author{
Курочкин Александр Владимирович
}

Доктор исторических наук, профессор,

ORCID: 0000-0002-3365-7266,olexkuro@gmail.com,

Киевский национальный университет культуры и искусств,

Киев, Украина

Цель статьи - критически проанализировать практику формирования системы советских праздников и обрядов, раскрыть их антигуманную, тоталитарную сущность и несоответствие целям и задачам построения демократического общества. В статье использованы общенаучные методы анализа и синтеза. Исторический метод помог в накоплении первичных данных, полученных из первоисточников и литературы по выбранной теме. Аксиологический метод позволил рассмотреть ценностный смысл и социальную важность советской ритуалистики. Научная новизна статьи определяется тем, что впервые в отечественной культурологии процессы внедрения и трансформации советских праздников и обрядов в Украине освещаются в контексте формирования идеологии тоталитарного режима. На конкретных фактах показано, что с самого начала большевистская власть осуществляла политику принудительной секуляризации населения, вытеснение из обихода (прежде всего общественного) всех форм и проявлений религиозной и традиционно народной ритуалистики. Выводы. В своем развитии советские праздники и обряды прошли несколько этапов, каждый из которых соответствовал определенному периоду становления социально-экономических отношений в Стране Советов, актуальным задачам в сфере преобразования идеологии и культуры. Ядром системы праздничных дат «красного календаря» стали годовщины Великой Октябрьской социалистической революции, День международной солидарности трудящихся, День Парижской коммуны. Официальные модели и сценарии этих торжеств обрели канонические формы в годы полного господства сталинской тоталитарной диктатуры. Так называемые новые социалистические обычаи и обряды страдали от избыточной регламентации, фальшивой патетики, передозировки коммунистической пропагандой, и поэтому, не случайно, их сравнивали с искусственными цветами. Одним из главных недостатков советской общесоюзной обрядности, которая в конечном итоге привела к ее полному банкротству, следует признать полное игнорирование самобытности культуры отдельных народов, населявших СССР.

Ключевые слова: советские праздники и обряды; коммунистический тоталитаризм; атеистическая пропаганда; праздничный календарь; национальная идентичность; демократическое общество. 